\title{
Physical activity, overweight and obesity in public service drivers in the city of Manizales, colombia
}

\author{
Luis Gerardo Melo-Betancourt* \\ Juan Camilo Castaño-Marín** \\ William Narváez-Solarte***
}

Recibido 08 de diciembre de 2019 Aceptado 26 de agosto de 2020

\begin{abstract}
Citar este artículo así:
Melo-Betancourt LG. Castaño-Marín JC. Narváez-Solarte W. Physical activity, overweight and obesity in public service drivers in the city of Manizales, Colombia. 2020; 26 (1): 125-140 DOI: 10.17151/hpsal.2021.26.1.11
\end{abstract}

\begin{abstract}
Objective: To determine the level of physical activity, overweight and obesity of public service drivers in the city of Manizales, Colombia. Methodology: quantitative, correlational and cross-sectional research. Simple random probability sampling. A sample of 175 male subjects was obtained from three public taxi service companies. The analysis was carried out with the SPSS v.20 program for Windows. Descriptive statistics were calculated. To determine the relationship between nonparametric variables, the MannWhitney U tests, Chi-square and the Pearson correlation index were applied. For the comparison of means in the parametric variables the t-Student test was used with a level of significance of $\mathrm{p} \leq$ 0.05 . Results: average age, $48.89 \pm 16.64$ years; average height, $1.68 \pm 0.05 \mathrm{~m}$, average abdominal circumference, $94.92 \pm 9.0 \mathrm{~cm}$ and average body mass index, $27.51 \pm 3.4 \mathrm{~kg} / \mathrm{m}^{2}$. Intense physical activity was carried out by $19.3 \%$, moderate intensity physical activity was practiced by $27.8 \%$, and low intensity physical activity was carried out by $36.4 \%$, while $16.5 \%$ of drivers do not perform any physical activity. Conclusions: Taxi drivers have low levels of intense and moderate physical activity while low levels of physical activity have a higher prevalence. Drivers are characterized because they are $63 \%$ overweight and have a high abdominal circumference index with values similar to the national parameters.

\section{Key words}

Obesity, physical activity, body mass index, Drivers (source: $M e S H, N L M$ ).

\footnotetext{
"School gymnastics specialist. Ph.D. Academy of Physical Culture of Moscow. Professor University of Caldas, Manizales Colombia. Author for correspondence. E-mail: luis.melo@ucaldas.edu.co. (D) orcid.org/0000-0003-2745-9027. Google

${ }^{* *}$ Mg. In Sport. National University of La Plata. Professor University of Caldas. Manizales. Colombia. E-mail: castano@ucaldas.edu.co. (1D) orcid.org/0000-0002-0841-9733. Google

${ }^{* * *}$ Ph.D Animal Nutrition. Unesp, Botucatu. Professor University of Caldas. Manizales. Colombia. E-mail: wnarvaez@ucaldas.edu.co. (D) orcid.org/0000-0003-4698-3818. Google
}

Hacia promoc. salud., Volumen 26, No.1, enero - junio 2021, págs. 125-140 ISSN: 0121-7577 (Impreso) ISSN: $2462-8425$ (En línea) 


\title{
Actividad física, sobrepeso y obesidad en conductores de servicio público de la ciudad de Manizales, Colombia
}

\begin{abstract}
Resumen
Objetivo: determinar el nivel de actividad física, sobrepeso y obesidad en los conductores de servicio público de la ciudad de Manizales, Colombia. Metodología: investigación de tipo cuantitativo, correlacional y de carácter transversal. Muestreo probabilístico aleatorio simple; se obtuvo una muestra de 175 sujetos del género masculino, de tres empresas de servicio público de taxis. El análisis se realizó con el programa SPSS v.20 para Windows. Se calcularon los estadísticos de tipo descriptivo; para determinar la relación entre variables no paramétricas se aplicaron las pruebas U de Mann-Whitney, Chi-cuadrado y el índice de correlación de Pearson. Para la comparación de medias en las variables paramétricas se usó la prueba t-Student, con un nivel de significancia de $\mathrm{p} \leq 0,05$. Resultados: edad promedio de 48,89 $\pm 16,64$ años; talla de 1,68 $\pm 0,05 \mathrm{~m}$, circunferencia abdominal de $94,92 \pm 9,0 \mathrm{~cm}$ y un índice de masa corporal de $27,51 \pm 3,4 \mathrm{~kg} / \mathrm{m}^{2}$; la actividad física intensa es realizada por el 19,3\%; la actividad física de intensidad moderada fue practicada por el $27,8 \%$, y la actividad física de baja intensidad fue realizada por el 36,4\%. El 16,5\% no realiza actividad física. Conclusiones: Los conductores de taxi tienen bajos niveles de actividad física intensa y moderada, mientras que los niveles de actividad física baja tienen una prevalencia más alta. Se caracterizan por presentar sobrepeso del $63 \%$ y un elevado índice de circunferencia abdominal, con valores similares a los parámetros nacionales.
\end{abstract}

\section{Palabras clave}

Obesidad, actividad física, índice de masa corporal, conductores (fuente: DeCS, BIREME).

\section{Atividade física, sobrepeso e obesidade nos motoristas do transporte público em Manizales, Colômbia}

\begin{abstract}
Resumo
Objetivo: determinar o nível de atividade física, sobrepeso e obesidade nos motoristas de transporte público da cidade de Manizales, Colômbia. Metodologia: pesquisa de tipo quantitativo, correlacional e de caráter transversal. Amostragem probabilística aleatória simples; foi obtida uma amostra de 175 sujeitos do gênero masculino, de três empresas de transporte público de taxis. A análise se realizou com o programa SPSS v.20 para Windows. Foram calculados os estatísticos de tipo descritivo; para determinar a relação entre variáveis não paramétricas foram aplicados os testes U de Mann-Whitney, Chi-quadrado e o índice de correlação de Pearson. Para a comparação de médias nas variáveis paramétricas foi usado o teste t-Student, com um nível de significância de $\mathrm{p} \leq 0,05$. Resultados: idade média de 48,89 $\pm 16,64$ anos; tamanho de $1,68 \pm 0,05 \mathrm{~m}$, circunferência abdominal de $94,92 \pm 9,0 \mathrm{~cm}$ e um índice de massa corporal de $27,51 \pm 3,4 \mathrm{~kg} / \mathrm{m}^{2}$; a atividade física intensa é realizada por $19,3 \%$; a atividade física de intensidade moderada é praticada por $27,8 \%$, e a atividade física de baixa intensidade é realizada é $36,4 \%$. O 16,5\% não realiza atividade física. Conclusões: Os motoristas de taxi têm baixos níveis de atividade física intensa e moderada, enquanto que os níveis de atividade física baixa têm uma prevalência mais alta. Um 63\% dos motoristas apresentou um elevado índice de circunferência abdominal, com valores similares aos parâmetros nacionais.
\end{abstract}

Palavros chave

Obesidade, atividade física, índice de massa corporal, motoristas (fonte: DeCS, BIREME). 


\section{Introduction}

Obesity (OB) is a multifactorial chronic disease established by an imbalance between energy intake and energy expenditure and other factors producing an accumulation of fat (1). This is the most frequent chronic metabolic disease reaching global epidemic dimensions. Its prevalence has doubled in the last three decades in all countries becoming an important public health problem in both developed and less favored societies (2). The World Health Organization (WHO) reveals that $39 \%$ of adults over 18 years of age are overweight $(\mathrm{O} / \mathrm{W})$ and $13 \%$ are obese $(\mathrm{OB})(3)$. In Colombia, according to the National Survey of the Nutritional Situation (ENSIN for its acronym in Spanish) the prevalence of $\mathrm{O} / \mathrm{W}$ is $37.8 \%$ and $\mathrm{OB}$ is $18.7 \%$ in adults between 18 and 64 years of age (4).

Within this framework, OB must be considered a risk factor for morbidity and premature mortality, due to the multiple consequences for the health and quality of life of the people who suffer from it. It is considered a risk factor for more than twenty chronic conditions, including: type 2 diabetes (T2D), hypertension (HT), dyslipidemia, cardiovascular disease (CVD), stroke, obstructive sleep apnea-hypopnea syndrome (OSAHS) (2) and more than ten types of cancer (5). Epidemiological studies have identified high body mass index (BMI) as a risk factor for an expanding group of chronic diseases (6-7). However, although BMI is not a good indicator of adiposity, it is the most used in most epidemiological studies and the one recommended by scientific societies to define and grade $\mathrm{OB}(2)$.

In relation to abdominal obesity particularly, it has been associated with metabolic alterations that increase the risk of CVD. In people with excess body fat, alterations in carbohydrate metabolism have been identified, such as: insulin resistance, glucose intolerance and incidence of T2D. There are also changes in lipid metabolism, with cases of dyslipidemia, elevated triglycerides, increased concentration of total cholesterol and low-density lipoproteins at the same time that the level of high-density proteins (8) lowers. Abdominal adiposity is directly correlated with metabolic and cardiovascular alterations secondary to $\mathrm{OB}$. The abdominal circumference (AC) measurement is a good indicator of abdominal fat so, central obesity is defined as an increase in $\mathrm{AC}$ which is the sum of subcutaneous abdominal fat and visceral abdominal fat, the latter being more important in the pathophysiology of excess weight, as it is more active from the metabolic point of view (2).

The modern lifestyle leads to physical inactivity understood as sedentary behavior. This behavior is described in the International Journal of Behavioral Nutrition and Physical Activity as a distinct class of activities that requires low levels of energy expenditure in the range of 1.0 to 1.5 METs (multiples of basal metabolic rate) that involve sitting during trips on the road, in the workplace, in the home environment, and during free time. At present, the use of electronic equipment with screens such as televisions, cell phones and video games has been one of the promoters of the increase in this behavior (9). According to the WHO 23\% of men over 18 years of age worldwide are not sufficiently active. In high-income countries, 26\% of men and $35 \%$ of women do not get enough physical exercise compared to $12 \%$ of men and $24 \%$ of women in low-income countries (10). In Colombia, according to the ENSIN, only $23.5 \%$ of the population between 18 and 64 years of age performs at least 150 minutes of physical activity (PA) during free time with inactivity being higher in men than in women (4).

This is how $\mathrm{O} / \mathrm{W}$ is associated with sedentary lifestyles, constituting PA as a determining factor for its prevention and that of various chronic diseases. PA does not only help prevent ailments like coronary heart disease, stroke, diabetes, depression, and various cancers but it also helps to avoid and control risk factors such as high cholesterol and hypertension, and it 
helps increasing the individual self-esteem and improving the perception of health-related quality of life (11). The Physical Activity Guidelines Advisory Committee Scientific Report (ANA) indicates that PA has a strong and positive impact on the health of people, reason why healthy adults, who are between 18 and 65 years of age, are recommended to perform 150 to 300 minutes per week of moderate intensity PA or 75 to 150 minutes per week of vigorous intensity aerobic $\mathrm{PA}$, or an equivalent combination of vigorous and moderate intensity aerobic activity (12).

Three-quarters of the population in Latin America have a sedentary lifestyle, the highest proportion is in the population with limited economic resources and, particularly, in women. The level of physical activity (LPA) of adults in the region is very low and tends to decrease as age advances (13). In the United States, more than $60 \%$ of adults do not achieve the recommended amount of weekly PA, and only $30 \%$ achieve it frequently. In this country, physical inactivity coupled with an inadequate diet account for $14 \%$ of annual deaths (14). In European countries such as Spain, the situation is no different. There are approximately $65.4 \%$ and $36.2 \%$ in the adult range who do not reach the acceptable levels of vigorous and moderate PA respectively (15).

It is important to highlight that the lack of PA in the population not only affects the health of people, but also the economic resources of the country. For example, in countries such as Australia, Canada, the United States, Switzerland and Brazil sedentary lifestyle is responsible for 2 to $6 \%$ of the total health expenditures (14).

In the Colombian context, the sedentary lifestyle figures are not different from those found in the aforementioned countries. Specific studies have been carried out in cities such as Barranquilla and Pamplona where it was found that $56.5 \%$ and $42.77 \%$ of the adults surveyed respectively have a sedentary behavior $(16,17)$. These proportions found by the researchers coincide with the national average found in the ENSIN. This survey affirms that $48.9 \%$ of Colombian youth and adults do not meet the minimum recommended LPA (4).

It should be noted that, together with age, gender and socioeconomic status among others, the profession of the individual is a factor that influences the prevalence of sedentary lifestyle and with it, the negative consequences on physical and health status. According to scientific research, people who work in the driving of vehicles constitute a population characterized by long hours of work without any PA, inadequate eating habits with diets rich in carbohydrates and lipids, high rates of smoking and altered sleeping habits. All these aspects that identify an unhealthy lifestyle become a trigger for this population group to develop clinical cases of psychological stress, uncontrolled increase in body weight, and to establish an epidemiological conditioning of pathological susceptibility to $\mathrm{O} / \mathrm{W}$ and $\mathrm{OB}$ (1819).

In the present case, the subject of study is the public service taxi drivers of Manizales, therefore, they are not exempt from sedentary lifestyle, poor diet and the risks of developing mainly clinical cases of $\mathrm{O} / \mathrm{W}$ and $\mathrm{OB}$. Thus, this population needs multidisciplinary intervention and requires a predominantly preventive approach and the promotion of healthy lifestyles.

Taking into account what was described above, and considering the scarcity of studies on the subject in Manizales, this research was carried out with the objective of determining the LPA, O/W and OB in public service drivers in the city of Manizales, Colombia. 


\section{Materials and Methods}

This research is quantitative, correlational and transversal in nature. A simple random probability sampling was carried out, in which taxi drivers were selected at random, provided they met the inclusion criteria, which consisted of being over 18 years old, being a driver of one of the legally constituted taxi companies, and having at least two years of experience in the job. The selected participants had to accept their partaking in the study voluntarily with prior signing of the informed consent. Those drivers with a recent history of surgery or some medical disability, and those who did not agree to participate voluntarily in the study, were excluded. In compliance with the above, from a universe of 2,583 drivers, a sample of 175 male subjects was obtained from the public taxi service companies Tax la Feria, Flota el Ruiz and Taxis Libres, in the city of Manizales. To determine the sample size, the mathematical model with a known sampling frame described below was used with an $\alpha$ of 0.05 and a precision of 0.05 . The research was carried out in the period between January and December 2018.

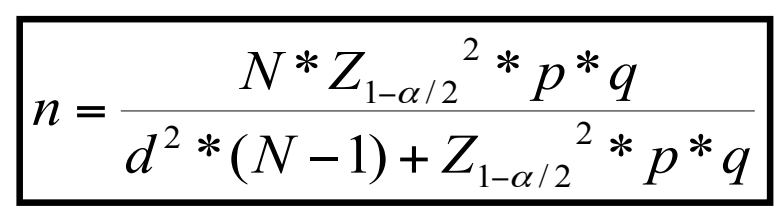

Sociodemographic characteristics were identified through a questionnaire that included questions regarding socioeconomic status, marital status, type of housing, years of work in the profession, level of education, gender, and age. The anthropometric characteristics including height, weight and AC were measured. The short Spanish version of the International PA Questionnaire (IPAQ) (20) developed by the WHO, which assesses the amount of PA of different intensities to identify PA levels, was used. The activities are divided into low, moderate and high intensity activities in days and minutes per week. The questionnaire has been used in various research projects (2122 ) and validated in nine countries (23) showing moderate to substantial reliability (Kappa: 0.670.73 ; Spearman's rho: $0.67-0.81$ ) and a validity from moderate to reasonable (Spearman's rho: 0.45-0.65). Anthropometric measurements were carried out according to the guidelines of the International Society for the Advancement of the Kinanthropometry - (ISAK) (24). Weight adjusted to $0.1 \mathrm{~kg}$, was determined and it was evaluated as follows: the subject, with the least amount of clothing possible and barefoot, without having any type of support and with his arms extended along the body was located in the center of the standing platform without having contact with surrounding objects. Once the referred position was adopted, the weight was read in kilograms. To measure height, the standardized stadiometer (Seca $700 \AA$ and Seca $220 \AA$ ) was used with adjustment to 0.5 $\mathrm{cm}$ and it was carried out as follows: the subject standing with the feet together with heels, buttocks, thoracic spine and neck leaning against the wall, the head in the Frankfort plane horizontalizing the trago-orbital line, the subject took an inspiration and held it while exerting firm upward pressure on the mastoids. The moving part of the height rod was slid until it came in contact with the vertex by pressing lightly (24). With the data of weight in $\mathrm{kg}$ and height in $\mathrm{cm}$, the BMI $=\left(\mathrm{kg} / \mathrm{m}^{2}\right)$ was calculated, classifying it according to the WHO criteria for the different degrees of OB. Through this method, normal weight: (BMI: $18.5-24.9 \mathrm{~kg} /$ $\mathrm{m} 2$ ); O/W: (BMI: 25-29.9 kg / m2) and OB: (BMI: $\geq 30 \mathrm{~kg} / \mathrm{m} 2$ ) (25) were considered. The $\mathrm{O} / \mathrm{W}$, $\mathrm{OB}$ and nutritional status values calculated were compared with the results obtained in men aged 18 to 64 years old of the Colombian population, as described in the ENSIN (4).

AC measurement was performed with a two-meter Rosscraft flexible and inextensible measure tape Lufking type. The procedure was carried out with the subject standing placing the measure tape in a direction parallel to the last floating rib. In this way, the natural waist contour was measured between 
the upper part of the hip bone (iliac crests) and the lower rib, measured during normal breathing and with a relaxed abdomen. The reading was recorded at the end of a normal expiration. The criteria of the International Diabetes Federation, which consider elevated and altered $\mathrm{AC}$ values as those equal to or greater than $90 \mathrm{~cm}$ (26) were taken into account for the interpretation of this variable.

The statistical analysis was carried out with the SPSS v.20 program for Windows. Descriptive statistics were calculated: mean, standard deviation and Confidence Interval $\left(\mathrm{CI}_{95 \%}\right)$. To determine the relationship between nonparametric variables, the Mann-Whitney U tests, Chi-square and the Pearson correlation index were administered. For the comparison of means in the parametric variables, the t-Student test was used, with a significance level of $p \leq 0.05$.

\section{Bioethical Considerations}

The participation of drivers was voluntary, bearing in mind Resolution 8430/1993, Art. 11 of the Ministry of Health in Colombia, (27) which establishes the scientific, technical and administrative standards for research in the area of Health (Republic of Colombia, 1993). The drivers were given an informed consent that stated the voluntary nature of their participation, guaranteeing anonymity and the certainty that the information collected would only be used for academic purposes. The study was classified as low risk and approved according to Act No. 13 of 2016 of the Bioethics Committee of the Faculty of Health Sciences at Universidad de Caldas.

\section{Results}

The anthropometric characteristics of the drivers of the city of Manizales involved in the study are presented in tables and text. Table 1 shows the mean, standard deviation, and the confidence interval of the selected sample of the variables age, weight, height, BMI, and AC.

Table 2 shows that $60.2 \%$ of these workers have more than ten years of work experience in the profession. It is also observed that $88.9 \%$ of them have a secondary, technical, technological and university education level while $11.1 \%$ have only basic primary education, highlighting the absence of illiterate taxi drivers. The distribution in percentage of the evaluated drivers, according to the marital status, reveals that $77.1 \%$ have a marital relationship either a marriage or de facto marital union, and only $10.6 \%$ correspond to single taxi drivers without marriage experience.

Table 1. Average and confidence interval $\left(\mathrm{CI}_{95 \%}\right)$ of the anthropometric characteristics of public taxi drivers in the city of Manizales

\begin{tabular}{lcc}
\hline CHARATERISTICS & Average \pm standard deviation & Confidence interval $\left(\mathbf{C I}_{\mathbf{9 5}^{\circ} \boldsymbol{*}}\right)$ \\
\hline Age $($ years $)$ & $48.89 \pm 16.64$ & $47.47-54.47$ \\
\hline Weight $(\mathrm{kg})$ & $77.58 \pm 11.6$ & $75.52-79.93$ \\
\hline Height $(\mathrm{m})$ & $1.68 \pm 0.05$ & $1.67-1.69$ \\
\hline BMI $\left(\mathrm{kg} / \mathrm{m}^{2}\right)$ & $27.51 \pm 3.4$ & $23.86-28.99$ \\
\hline Abdominal Circumference $(\mathrm{AC})$ & $94.92 \pm 9.0$ & $93.65-96.91$ \\
\hline
\end{tabular}


Table 2. Percentage distribution (\%) of public taxi drivers in Manizales according to work experience, level of education and marital status

\begin{tabular}{|c|c|c|c|c|c|c|}
\hline \multirow{2}{*}{ Taxi drivers } & \multicolumn{6}{|c|}{ Working experience (years) } \\
\hline & 1 a 3 & 4 a 6 & 7 a 9 & 10 a 12 & 13 a 15 & $>16$ \\
\hline \multirow[t]{3}{*}{$\%$} & 14.2 & 10.8 & 14.8 & 13.5 & 8.1 & 38.6 \\
\hline & \multicolumn{6}{|c|}{ Schooling } \\
\hline & Elementary & Secondary & Technical & Tech & gical & University \\
\hline \multirow[t]{3}{*}{$\%$} & 11.1 & 64.3 & 8.2 & & & 3.9 \\
\hline & \multicolumn{6}{|c|}{ Marital status } \\
\hline & Married & $\begin{array}{r}\text { De facto } M \\
\text { Union }\end{array}$ & & Divorced & & Single \\
\hline$\%$ & 51.2 & 25.9 & & 12.3 & & 10.6 \\
\hline
\end{tabular}

Source: self-made

The IPAQ information collection instrument (20) allowed classifying public service workers according to the intensity and frequency of PA and it was determined that: a) $19.3 \%$ of drivers perform high intensity PA during 15 to 30 minutes one to three days a week as shown in Table 3. Their average age is 47.4 years, average weight is 76.29 $\mathrm{kg}$, average height is $1.67 \mathrm{~m}$, average AC 94.01 $\mathrm{cm}$, an average BMI $27.10 \mathrm{~kg} / \mathrm{m} 2$ and $73.3 \%$ of them prefer biking, jogging, or aerobic exercise. b) $27.8 \%$ of taxi drivers perform PA of moderate intensity, such as jogging, with a weekly frequency of one to three days and a duration between 15 and 30 minutes per session. Their average age is 50.8 years, average weight $76.8 \mathrm{~kg}$, average height $1.67 \mathrm{~m}$, average AC $94.41 \mathrm{~cm}$ and average BMI $27.25 \mathrm{~kg} / \mathrm{m} 2$. c) $36.4 \%$ of the taxi drivers have a median age of 48.3 years, $77.38 \mathrm{~kg}$ average body weight, $1.69 \mathrm{~m}$ average height, $93.26 \mathrm{~cm}$ average AC, $27.08 \mathrm{~kg} / \mathrm{m} 2$ average BMI and they perform low intensity PA, highlighting that $51.5 \%$ prefer to walk between 15 and 30 minutes per day, three to four times a week. d) Finally, it was found that $16.5 \%$ of drivers have an average age of 48.9 years, $76.51 \mathrm{~kg}$ average weight, $1.66 \mathrm{~m}$ average height,
$95.98 \mathrm{~cm}$ average $\mathrm{AC}, 27.58 \mathrm{~kg} / \mathrm{m} 2$ average BMI and do not perform any PA other than work.

It should be noted that the main activity they carry out on their weekly day off is watching television and, as can be seen in Table 3,79.3\% of them dedicate between one and eight hours a day to this activity. Regarding the type of housing, related to ownership, $57.4 \%$ of workers own their own home while $42.6 \%$ live as tenants or live with their parents. Regardless the type of housing, $44.9 \%$ belong to the low socioeconomic class, $53.9 \%$ to the middle socioeconomic class and $1.2 \%$ to the high socioeconomic class.

When analyzing the results, no statistically significant association was found, by the $\mathrm{x}^{2}$ test, of the variables type of home, work experience, level of education, marital status and LPA, with the anthropometric variables age, weight, height and BMI. However, a statistically significant association $(p=0.04)$ was observed between the marital status and $\mathrm{AC}$ variables, since the average $\mathrm{AC}$ in married drivers is $96.71 \mathrm{~cm}$ and in those who live in de facto marital union is $93.11 \mathrm{~cm}$, being statistically 
superior $(\mathrm{p}<0.05)$ by the $\mathrm{t}-\mathrm{Student}$ test than the AC averages of the single and divorced people.

The results showed that the lack of PA negatively affects BMI, as well as AC. In this regard, taxi drivers who do not perform PA present the highest values of both BMI with $27.58 \mathrm{~kg} / \mathrm{m}^{2}$, as well as AC with $95.98 \mathrm{~cm}$. The means show statistically significant differences $(\mathrm{P}<0.05)$ for the t-Student test of those who either performed or did not perform high, moderate or low intensity PA. However, the statistically significant difference between the averages of BMI of those who practice and do not practice $\mathrm{PA}$, highlights that the averages of this variable and $\mathrm{AC}$ in the different LPA are above $27 \mathrm{~kg} / \mathrm{m} 2$ and $93 \mathrm{~cm}$, respectively. Therefore, if the criteria of the International Diabetes Federation are taken into account, it can be affirmed that, regardless drivers in Manizales perform or do not perform PA, they all present $\mathrm{BMI}$ values that indicate high $\mathrm{O} / \mathrm{W}$ and $\mathrm{CA}$, with values higher that the $90 \mathrm{~cm}$ barrier, which denotes risk of CVD (26).

Table 3. Percentage distribution (\%) of public taxi drivers in Manizales according to the characteristics of physical activity

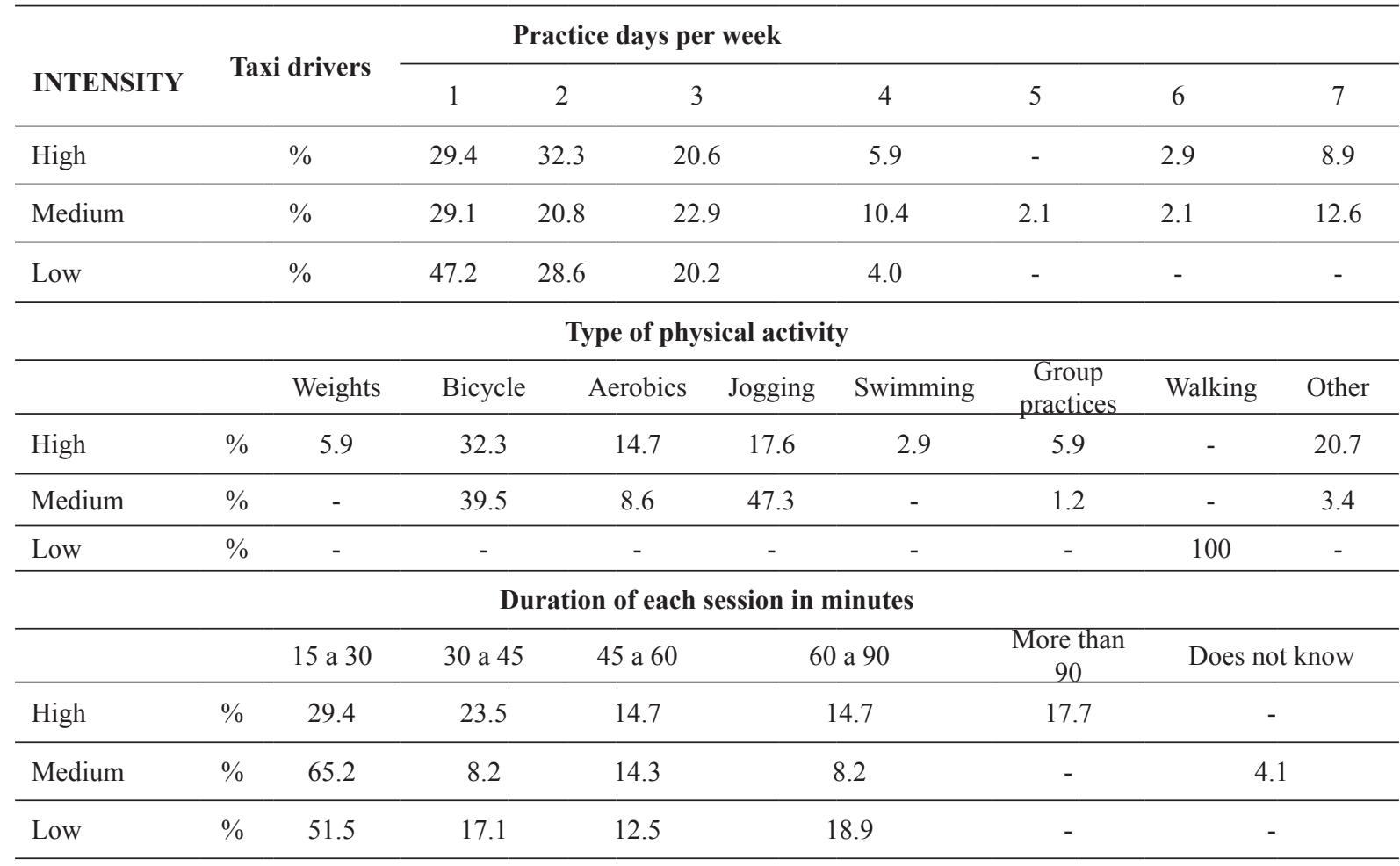

\begin{tabular}{lccccc}
\multicolumn{7}{c}{ Hours of television on days off, sitting or lying down } \\
\hline High & 0 & 1 a 3 & 3 a 5 & 6 a 8 \\
\hline Medium & $\%$ & 26.5 & 52.9 & 11.8 & 8.8 \\
\hline Low & $\%$ & 18.4 & 51.0 & 16.3 & 14.3 \\
\hline
\end{tabular}


When evaluating whether there was a correlation between the averages of the anthropometric variables through the Pearson's correlation test, a negative correlation $(-0.24)$ of age with height ( $p$ $=0.03)$ was found as well as a positive correlation (0.22) of age with CA $(\mathrm{p}=0.007)$. Body weight showed a positive correlation $(\mathrm{p}=0.00)$ with height (0.46), with BMI (0.89) and with AC (0.73). In the same way, there was a positive correlation (0.76) between BMI and CA $(p=0.00)$, Table 4.

Finally, when calculating the percentages of $\mathrm{O} / \mathrm{W}$ and nutritional status of the taxi drivers from
Manizales and comparing them with BMI and CA through the t-Student test with the corresponding national average value reported in the ENSIN (4), the percentage of $\mathrm{O} / \mathrm{W}$ shows statistically significant differences $(p<0.05)$; these values are higher in the taxi drivers of Manizales while the average of the BMI and the $\mathrm{AC}$ were statistically equal ( $p>0.05)$ to the Colombian national average (Figure 1). Notwithstanding these results, the classification of low nutritional status was not found in any of the evaluated subjects, which is an indicator that they do not suffer malnutrition.

Table 4. Age, weight, height, body mass index (BMI) and abdominal circumference (AC) means according to and physical activity their schooling, social class, marital status, years as a driver and type of housing in public taxi drivers from Manizales, Colombia

\begin{tabular}{|c|c|c|c|c|c|}
\hline & $\begin{array}{c}\text { Age } \\
\text { (years) }\end{array}$ & $\begin{array}{c}\text { Weight } \\
\text { (kg) }\end{array}$ & $\begin{array}{c}\text { Height } \\
(\mathrm{cm})\end{array}$ & $\begin{array}{c}\text { BMI } \\
\left(\mathrm{kg} / \mathrm{m}^{2}\right)\end{array}$ & $\begin{array}{c}\mathrm{AC} \\
(\mathrm{cm})\end{array}$ \\
\hline \multicolumn{6}{|l|}{ Schooling } \\
\hline Elementary & 55.05 & 73.42 & 1.65 & 26.72 & 93.57 \\
\hline Secondary & 49.31 & 77.67 & 1.67 & 27.58 & 95.49 \\
\hline Technical & 46.28 & 81.09 & 1.70 & 28.08 & 93.00 \\
\hline $\begin{array}{l}\text { Technological } \\
\text { and University }\end{array}$ & 42.00 & 75.83 & \multicolumn{2}{|c|}{ and University } & 91.33 \\
\hline$p$ value $=$ & 0.89 & 0.37 & 0.97 & 0.92 & 0.30 \\
\hline \multicolumn{6}{|l|}{ Social class } \\
\hline Low & 45.95 & 77.81 & 67.6 & 27.65 & 95.25 \\
\hline Medium & 51.05 & 77.07 & 67.9 & 27.29 & 93.97 \\
\hline High & 46.00 & 73.80 & 169.5 & 25.75 & 94.0 \\
\hline$p$ value $=$ & 0.93 & 0.64 & 0.86 & 0.97 & 0.91 \\
\hline \multicolumn{6}{|l|}{ Marital status } \\
\hline Single & 38.60 & 73.81 & 67 & 26.28 & $90.27 *$ \\
\hline Married & 51.26 & 79.20 & 168 & 27.96 & $96.71 * *$ \\
\hline Divorces & 53.11 & 70.97 & 166 & 25.66 & $90.75 *$ \\
\hline De facto & 45.76 & 77.64 & 168 & 27.45 & $93.11 * *$ \\
\hline \multicolumn{6}{|l|}{ Marital Union } \\
\hline$p$ value $=$ & 0.47 & 0.12 & 0.12 & 0.28 & 0.04 \\
\hline \multicolumn{6}{|l|}{$\begin{array}{l}\text { Years as a } \\
\text { driver }\end{array}$} \\
\hline 2 to 3 & $42.53 *$ & 78.92 & 169.3 & 27.49 & 93.93 \\
\hline 4 to 6 & $41.08 *$ & 78.66 & 170.6 & 26.93 & 92.84 \\
\hline 7 to 9 & $44.20 *$ & 78.79 & 166.0 & 28.53 & 93.67 \\
\hline 10 to 12 & $47.88^{*}$ & 77.21 & 168.1 & 27.31 & 96.00 \\
\hline 13 to 15 & $47.61 *$ & 75.56 & 166.8 & 27.16 & 92.57 \\
\hline$>16$ & $56.20 * *$ & 75.77 & 167.3 & 27.05 & 95.25 \\
\hline$p$ value $=$ & 0.00 & 0.99 & 0.25 & 0.79 & 0.51 \\
\hline \multicolumn{6}{|l|}{ Housing } \\
\hline Own house & 50.57 & 76.10 & 167.2 & $27.17 * *$ & 93.73 \\
\hline Not own house & 47.69 & 79.72 & 168.7 & $28.00^{*}$ & 96.72 \\
\hline$p$ valor $=$ & 0.63 & 0.07 & 0.66 & 0.00 & 0.74 \\
\hline
\end{tabular}

Source: self-made. Note: Means with the same number of asterisks within the same column ( $>>0.05)$. 


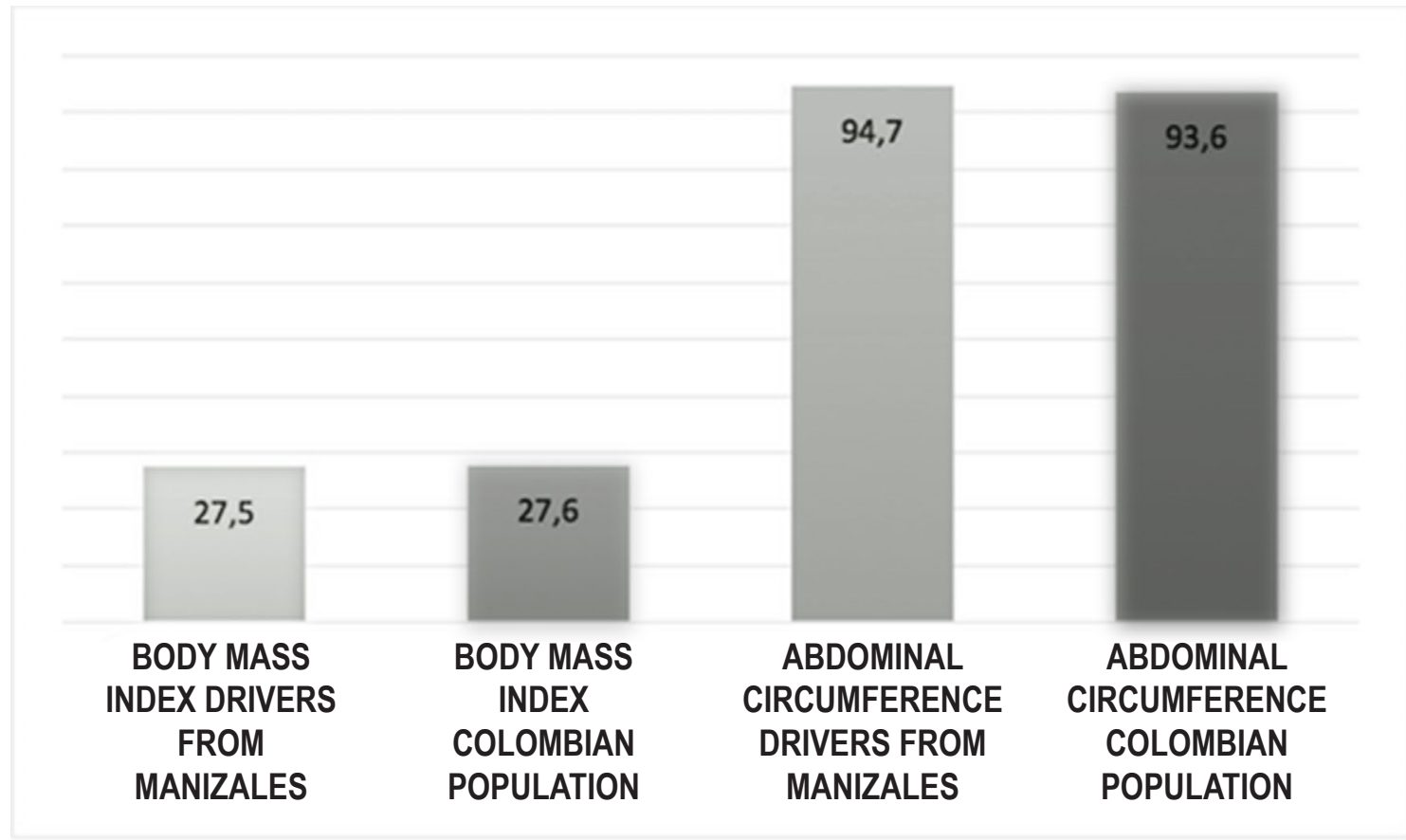

Figure 1. Nutritional status according to body mass index $\left(\mathrm{kg} / \mathrm{m}^{2}\right)$ and abdominal circumference $(\mathrm{cm})$ of public taxi drivers in Manizales and the Colombian population.

Source: self-made

\section{Discussion}

Regarding the level of schooling, the taxi drivers from Manizales affirmed that they all had completed their basic elementary education and a large part of secondary education. A low percentage of this population had technical, technological and university education. When comparing these proportions of educations level of drivers in Colombia, it was observed that the proportion with a university level is lower than that of the country, which has an average of $27.6 \%$ for men (4). However, the results are better than those of some countries in the region, including Brazil, where secondary education reaches 30\% and only $1 \%$ of taxi drivers completed university education (28). Therefore, the absence of illiterate drivers in the city of Manizales is highlighted and, on the contrary, the similarity in the proportion with secondary education training similar to the average of taxi drivers in developed countries such as the United States, where the average is $61.5 \%$, is highlighted.

The average age of the taxi drivers of Manizales is $48.89 \pm 16.64$, is a similar value to that of the public service drivers of several cities in Colombia and to that reported in several countries such as the United States with $45 \pm 10,75$ years (29), Spain with $40.6 \pm 10.7$ years (30), Brazil with $41.9 \pm 10$ years (31) and India with $41.38 \pm 10.45$ years (32). Therefore, since aging is a predisposing factor to sedentary lifestyle and a decrease in PA and the taxi drivers evaluated have a high age, it can become a contributing factor to the emergence of health risk diseases due to sedentary behavior. 
The average $\mathrm{AC}$ measured in taxi drivers in the city of Manizales was $94.92 \pm 9.0 \mathrm{~cm}$. Although it is a value that exceeds the $90 \mathrm{~cm}$ threshold, it is below the $103.3 \mathrm{~cm}$ recorded as the average of the general population determined in several cities in Colombia $(33,34)$. However, when comparing the average of the AC found with people who perform the same activity internationally, it was found that this value is higher than that of the drivers in Taiwan who have an average of $88.7 \mathrm{~cm} \mathrm{AC} \mathrm{(35)} \mathrm{and} \mathrm{similar} \mathrm{to}$ the $94.4 \mathrm{~cm}$ average of Brazilian drivers (31).

Abdominal obesity, determined from AC measurement, is a reliable indicator of the level of intra-abdominal adiposity. This condition is directly related to an increase in insulin resistance, hyperglycemia, dyslipidemia and hypertension, conditions that greatly increase the possibility of suffering complications derived from cardiovascular risk (36). The International Day for Evaluation of Abdominal Obesity took place simultaneously in 63 countries including Colombia and had the participation of 168,000 patients. Central OB was determined as a marker of increased intra-abdominal adiposity and as a higher risk factor for atherosclerosis and diabetes than BMI, it is also a good risk predictor of cardiovascular morbidity, metabolic syndrome and diabetes (37).

According to the results obtained in this study, there is a $63 \%$ prevalence of $\mathrm{O} / \mathrm{W}$ in public service taxi drivers in Manizales. Studies on the same topic in cities such as Medellín (38) and Cali (34) also found a lower proportion of taxi drivers with $\mathrm{O} / \mathrm{W}$ and $\mathrm{OB}$, with values of $44.2 \%$ and $38 \%$, respectively. In the international arena, $27.4 \%$ of Spanish drivers suffer from OB (30), in India $36.2 \%$ suffer $\mathrm{O} / \mathrm{W}$ and $34.8 \%$ suffer OB (32), in Brazil $72.8 \%$ suffer $\mathrm{O} / \mathrm{W}$ (28), in Mexico the prevalence of $\mathrm{O} / \mathrm{W}$ is $42.5 \%$ and of OB $34.5 \%$ (39), while in Peru, a country with environmental and sociodemographic conditions more similar to those of Colombia, it was observed that $51.2 \%$ of the drivers suffer $\mathrm{O} / \mathrm{W}$ and $21.3 \%$ suffer OB (40). Therefore, all the results corroborate that the people dedicated to driving vehicles constitute a population susceptible to suffering from clinical cases of $\mathrm{O} / \mathrm{W}$ and $\mathrm{OB}$, regardless the region or country.

The statement that the accumulation of abdominal fat and $\mathrm{OB}$ double the risk of mortality, and that the risk of mortality in people is proportional to $\mathrm{AC}$, in spite of the smoking habit, the health status of the individual or the ethnic group to which he belongs, was the conclusion reached after epidemiological follow-up of 360,000 people from nine European countries for 10 years (41) and the results of a study by the United States National Institutes of Health which included a quarter of a million patients over a period of 9 years (42).

The distribution of the drivers from Manizales, according to the intensity of the PA performed in the seven days prior to the evaluation, allowed observing that $19.3 \%$ performed $\mathrm{PA}$ of high intensity, $27.8 \%$ performed PA of moderate intensity, $36.4 \%$ performed low intensity PA while $16.5 \%$ did not perform any PA. The physical activities with the highest frequency were cycling, jogging, and aerobic exercises. The length of the sessions, that concentrated most of the drivers, was between 15 and 45 minutes, held one to three days per week. Low-intensity physical activities were the most performed since they are part of their daily lives where $68.6 \%$ say they walk between 15 and 45 minutes per session.

According to the ENSIN (4), only $21 \%$ of the population between 18 and 64 years old in Colombia perform at least 150 minutes of PA weekly during their free time as recommended by the Physical Activity Guidelines Advisory Committee Scientific Report (12). Studies with drivers in Medellín (38) show that $60.5 \%$ perform PA once per week, $23.1 \%$ between two and three days and only $16 \%$ more than three days per week. Regarding the time per session, it was evidenced that $46.9 \%$ do less than 30 minutes on average, $29.2 \%$ do between 30 minutes and one hour and 
$23.8 \%$ more than one hour. Another research with workers in the city of Villavicencio reports that $45.5 \%$ of the men surveyed consider themselves physically active. (43).

Cases similar to the Colombian situation regarding the practice of PA by workers in their free time have been found in countries such as Argentina, Peru and Spain. In the city of Córdoba, a study shows that $60.5 \%$ of the people evaluated have a low LPA regardless their gender, and that in general the group studied spends 23.2 minutes on a daily walk, 8.6 minutes on moderate physical activity and 7.3 minutes a day on intense physical activity (44). In the same way, another study showed that the weekly PA performed by male drivers in Spain is $35.1 \%$ (30). The most critical case is the one found when evaluating public transport drivers in Peru, who present a proportion of $81.2 \%$ of taxi drivers with physical inactivity versus $18.8 \%$ who reach the minimum threshold of PA (40). In the Latin American region, it is worth highlighting the figures for Uruguay where $86.4 \%$ of people perform 150 or more minutes of PA per week (45), results far superior to those found in the present research.

The results obtained in this research and those findings of other research projects show that the majority of the members of the population of transportation drivers do not achieve the minimum threshold of weekly PA recommended in the physical activity guidelines of the Department of Health and Human Services of United States, which are necessary to maintain a regular health state (12). It has been demonstrated that PA practiced frequently and with high intensity and duration is the most effective treatment for the control of $\mathrm{O} / \mathrm{W}$ and $\mathrm{OB}$. However, this type of PA is not frequent in public service taxi drivers (44) whose occupational characteristics and workload characterize them in a profile prone or sensitive to developing $\mathrm{O} / \mathrm{W}$. In addition, the physical, mental and social wear and tear that the development of the work day can generate for the driver have a great almost inevitable influence on their lifestyle including the decrease in the practice of PA (43).

As this research is a cross-sectional study, it does not allow conclusions regarding a causal relationship between $\mathrm{O} / \mathrm{W}$ and the practice of $\mathrm{PA}$. Also, it is not possible to determine whether these low PA patterns were previous to $\mathrm{O} / \mathrm{W}$ or changed after weight gain. Therefore, these findings give rise to justifying longitudinal studies that evaluate the variables studied in different populations of drivers of different modalities. This study focused on the population dedicated to driving public service taxis as a sample of the situation of quality of life related to health and the problem of $\mathrm{O} / \mathrm{W}$ due to the lack of PA in the driving profession in the city of Manizales - Colombia. The results obtained provide new and feasible information for the planning of policies that promote healthy lifestyle habits such as the practice of regular physical activity and that improve the general quality of life of adults.

This study shows the importance of incorporating educational, informative and practical programs in public taxi companies because they have a great impact on the quality of working life and on the health of drivers. There are studies that show the health and business savings when the companies invest in the physical activity of workers. Reducing excess sedentary lifestyle is another task to be carried out. To achieve this purpose, it is necessary to design interventions aimed at problems such as $\mathrm{O} / \mathrm{W}$ and $\mathrm{OB}$ providing a healthy organizational climate where quality of life, health and wellbeing in general are reflected.

\section{Conclusions}

Public taxi drivers in Manizales have low levels of intense and moderate physical activity, while low levels of physical activity have a higher prevalence. They are characterized by being $63 \%$ overweight and having a high abdominal circumference index with values similar to the national parameters. 


\section{Recommendations}

The urgent need to plan interventions aimed at counteracting the risk factors present in this study group, such as sedentary lifestyle and being overweight, emerges from the foregoing. Despite the multiple health benefits of physical exercise, sedentary lifestyle increases to worrying levels if social groups are not intervened. Therefore, the companies involved in the study are recommended to implement prevention and intervention programs of an educational nature by specialized professionals so that their workers include physical activity in their daily lives on a regular basis accompanied by good eating habits.

\section{Acknowledgments}

To the vice-rector for Research and Graduate Studies at Universidad de Caldas (Colombia) for the financial support. To the students of the Physical Activity and Sports Seedbed at Universidad de Caldas for their collaboration, and to the drivers of the Tax la Feria, Flota El Ruiz and Taxis Libres companies in the city of Manizales, for participating in the study.

\section{Conflict of interests}

The manuscript was prepared and reviewed with the participation of all the authors who declare that there is no conflict of interest that puts the validity of the results presented at risk. 


\section{Bibliographic References}

1. San Mauro I, Garicano E, Cordobés M, Díaz P, Cevallos V, Pina D, Paredes V. Exceso ponderal infantil y adolescente: factores modificables, herencia genética y percepción de la imagen corporal. Rev Pediatr Aten Primaria. 2016; 18: 199-208.

2. González J, Ruiz-Tovar Polo J, Durán M. Principios de la obesidad mórbida. Dykinson: 2017.

3. Organización Mundial de la Salud (OMS). Obesidad y sobrepeso. [Internet]. 2020. Available from:https://www.who.int/es/news-room/fact-sheets/detail/obesity-and-overweight

4. Colombia. Ministerio de Salud. Encuesta Nacional de Situación Nutricional. Available from: https:// www.nocomasmasmentiras.org/wp-content/uploads/2017/12/Resultados-ENSIN-2015.pdf.

5. Petrova D, Salamanca-Fernandez E, Rodriguez M, Navarro P, Jimenez JJ, Sanchez M-J. Obesidad como factor de riesgo en personas con COVID-19: posibles mecanismos e implicaciones. Atención Primaria. 2020; 52 (7): 496-500.

6. Singh GM, Danaei G, Farzadfar F, Stevens GA, Goodwar M, Wormser D, et al. The age-specific quantitative effects of metabolic risk factors on cardiovascular diseases and diabetes: a pooled analysis. PLoSOne. 2013; 8(7): 65174. https://doi.org/10.1371/journal.pone.0065174

7. Wormser D, Kaptoge S, Di Angelantonio E, Wood AM, Pennells L, Thompson A, et al. Separate and combined associations of body-mass index and abdominal adiposity with cardiovascular disease: collaborative analysis of 58 prospective studies. Lancet. 2011; 377 (9771): 1085-95. https://doi. org/10.1016/S0140-6736(11)60105-0

8. García AI, Nino-Silva L, González-Ruiz K, Ramírez-Vélez R. Volumen de grasa visceral como indicador de obesidad en hombres adultos. Revista Colombiana de Cardiología. 2016; 23 (4): 313 320. http://dx.doi.org/10.1016/j.rccar.2015.12.009

9. Tremblay MS, Aubert S, Barnes JD, Saunders TJ, Carson V, Latimer-Cheung AE, et al. Sedentary Behavior Research Network (SBRN).Terminology Consensus Project process and outcome. International Journal of Behavioral Nutrition and Physical Activity; 2017; 14(1):75. https://doi. org/10.1186/s12966-017-0525-8

10. Organización Mundial de la Salud (OMS). Actividad física. [Internet]. 2018; Available from:https:// www.who.int/es/news-room/fact-sheets/detail/physical-activity

11. Martín-Doménech A, Peiró-Pérez R, Esplugues A, Castán S, Legaz-Sánchez E, Pérez-Sanz E. Valoración de un programa piloto de prescripción de actividad física en atención primaria en la Comunitat Valenciana. Gaceta sanitaria. 2020. https://doi.org/10.1016/j.gaceta.2020.04.021

12. Expert Panel on Integrated Guidelines for Cardiovascular Health and Risk Reduction in Children and Adolescents; National Heart, Lung, and Blood Institute. Expert panel on integrated guidelines for cardiovascular health and risk reduction in children and adolescents: summary report. Pediatrics. 2011; 128 (Suppl 5): p. S213 - 56. https://doi.org/10.1542/peds.2009-2107C

13. Salazar JG, Torres TM, Aranda C, López A. Calidad de vida relacionada con la salud y obesidad en el personal docente universitario de Jalisco, México. Actualización en Nutrición. 2016; 17: 79-86.

14. Alfonso-Mora ML, Vidarte-Claros JA, Vélez Álvarez C, Sandoval Cuéllar C. Prevalencia de sedentarismo y factores asociados, en personas de 18 a 60 años en Tunja, Colombia. Rev. Fac. Med. 2013; 61 (1): 3-8.

15. Mielgo-Ayuso J, Aparicio-Ugarriza R, Castillo A, Ruiz E, Ávila JM, Aranceta-Batrina J, et al. Physical Activity Patterns of the Spanish Population Are Mostly Determined by Sex and Age: Findings in the ANIBES Study. PLoS ONE. 2016; 11(2): e0149969. https://doi.org/10.1371/journal. pone. 0149969 
16. De Caro Guerra A, Madera L, Pozzo J, Torres M. Nivel de actividad física, sedentarismo y condición física saludable en adultos de 18 a 42 años en una Universidad de Barranquilla. Revista salud en movimiento. 2016; 8 (1): 14-24.

17. Moreno JA. Niveles de sedentarismo en estudiantes universitarios de pregrado de Colombia. Revista cubana de salud Pública. 2018;44 (3):553-566.

18. Rodríguez-Miranda CD, Jojoa-Ríos, JD, Orozco-Acosta LF, Nieto-Cárdenas OA. Síndrome metabólico en conductores de servicio público en Armenia, Colombia. Revista de Salud Pública. 2017; 19 (4): 499-505.

19. Moreno B. Factores y riesgos laborales psicosociales: conceptualización, historia y cambios actuales. Med Segur Trab. 2011; 57. Suplemento 1: 1-262.

20. Organización Mundial de la Salud (OMS). Cuestionario Global de Actividad Física. 2007. Available from: https://www.who.int/ncds/surveillance/steps/GPAQ_ES.pdf.

21. Abu-Omar K, Rütten A. Relation of leisure time, occupational, domestic, and commuting physical activity to health indicators in Europe. Preventive Medicine, 2008; 47 (3): 319-323.

22. Bauman AE, Nelson DE, Pratt M, Matsudo V, Schoeppe S. Dissemination of Physical Activity Evidence, Programs, Policies, and Surveillance in the International Public Health Arena. American Journal of Preventive Medicine. 2006; 31 (4): 57-65.

23. Bull FC, Maslin TS, Armstrong T. Global Physical Activity Questionnaire (GPAQ): Nine Country Reliability and Validity Study. Journal of Physical Activity and Health. 2009; 6 (6): 790-804.

24. Marfell-Jones M, Olds T, Stewart A, Carter L. International Standards for Anthropometric Assessment. New Zealand. Lower Hutt International Society for the Advancement of Kinanthropometry; 2011. $137 \mathrm{p}$.

25. Quijada RV, Aguilar JL. Factores de riesgo cardiovascular modificables en conductores de transporte público empresa de transportes santo cristo de pachacamilla s.a. Universidad peruana Cayetano Heredia; 2018.

26. FID. Diabetes Atlas de la FID [Internet]. Bruselas: FID; 2017. 143 p. Available from: www. diabetesatlas.org

27. Colombia. Ministerio de Salud. Resolución Número 8430 de 1993.. Available from: https://www. minsalud.gov.co/sites/rid/Lists/BibliotecaDigital/RIDE/DE/DIJ/RESOLUCION-8430-DE-1993. PDF

28. Eshwaran S, Sampath S, Arun D, Sravan S. Epidemiological study of cardiovascular risk factors among public transport drivers in rural area of Chittoor district of Andhra Pradesh. International Journal of Community Medicine and Public Health. 2015; 2 (4): 415-420.

29. National Health and Nutrition Examination Survey. Anthropometry Procedures Manual. 2007.

30. Elshatarat RA, Burgel BJ. Cardiovascular Risk Factors of Taxi Drivers. Journal of Urban Health. 2016; 93 (3): 589-606.

31. González AA, Llinás M, Carmona M, González I, Janer P, Casquero R. Valoración del Riesgo Cardiovascular en Varones Conductores Profesionales del Área Mediterránea Española y Variables Asociadas. Ciencia \& Trabajo. 2018; 20 (61): 1 -6.

32. Hirata RP, Sampaio LM, Studart FS, Braghiroli A, Balbi B, Romano S, et al. General characteristics and risk factors of cardiovascular disease among interstate bus drivers. The Scientific World Journal.2012; 216-702.

33. Delgado C, García MA. Caracterización de factores de riesgo en población de conductores de servicio público diagnosticados con infarto agudo de miocardio, clínica Cardio Vid, Medellín 2014 - 2015. Colombia. Universidad CES; 2017. 
34. Cardona SF, Pérez MF. Factores de riesgo cardiovascular en un grupo de conductores que laboran en una empresa de servicios especiales de transporte de pasajeros de la ciudad de Medellín. Colombia. Universidad CES; 2015.

35. Szu-Chia C, Jer-Ming C, Ming-Yen L, Meng-Ling H, Jer-Chia T, Shang-Jyh H, Hung-Chun C. Association of metabolic syndrome and albuminuria with cardiovascular risk in occupational drivers. Int J Mol Sci. 2013; 14(11): 21997-22010

36. Bryce-Moncloa A, Alegría-Valdivia E, San Martin-San Martin MG. Obesidad y riesgo de enfermedad cardiovascular. Simposio Obesidad. 2017; 78 (2): 202-206.

37. Ruiz AJ, Aschner PJ, Puerta MF, Cristancho RA. Estudio IDEA (International Day for Evaluation of Abdominal Obesity): prevalencia de obesidad abdominal y factores de riesgo asociados en atención primaria en Colombia. Biomédica. 2012; 32 (4): 610-616.

38. Sangaleti CT, Trincaus MR, Baratieri T, Zarowy K, Ladika MB, Menon MU, et al. Prevalence of cardiovascular risk factors among truck drivers in the South of Brazil. BMC Public Health. 2014; 14:1063.

39. Camargo-Escobar FL, Gómez-Herrera OL, López-Hurtado MX. Riesgo cardiovascular en conductores de buses de transporte público urbano en Santiago de Cali, Colombia. Revista Colombiana de Salud Ocupacional. 2013; 3 (3):18-22.

40. Hall JA, Ochoa PY, Alarcón EI. Physical activity, nutritional status and abdominal obesity amongst physical education teachers. Revista Internacional de Medicina y Ciencias de la Actividad Física y el Deporte. 2012; 12 (46): 209-220.

41. Schneider HJ, Glaesmer H, Klotsche J, Böhler S, Lehnert H, Zeiher AM, et al. Accuracy of anthropometric indicators of obesity to predict cardiovascular risk. The Journal of Clinical Endocrinology \& Metabolism. 2007; 92(2):589-94.

42. Amato MC, Giordano C, Galia M, Criscimanna A, Vitabile S, Midiri M. Visceral Adiposity Index: A reliable indicator of visceral fat function associated with cardiometabolic risk. Diabetes Care. 2010; 33(4): 920-922.

43. Colmenares JA, Herrera R. Prevalencia de actividad física y beneficios y barreras en trabajadores de Villavicencio, Colombia. Rev Univ Ind Santander Salud. 2018; 50 (1): 37-45.

44. García AL, Rodríguez A. Riesgo cardiovascular: Asociación con ingesta de lípidos, actividad física y conductas sedentarias en adultos de la provincia de Córdoba en el año 2015. Argentina. Universidad nacional de córdoba; 2016.

45. Skapino E, Alvarez R. Prevalencia de factores de riesgo de enfermedades crónicas no transmisibles en funcionarios de una institución bancaria del Uruguay. Revista Uruguaya de Cardiología. 2016; 31 (2): 246-255. 